\title{
Buildings of Performing Arts in Latvia's Modern Movement
}

\author{
Agate Eniṇa* \\ Riga Technical University, Faculty of Architecture and Urban Planning, Azenes Street 16/20-420, LV-1048, Riga, Latvia. \\ * corresponding author: E-mail: agate.enina@inbox.lv \\ cross $^{\text {ref }}$ http://dx.doi.org/10.5755/j01.sace.1.2.2840
}

After WWII, the Soviet Iron Curtain impeded sharing of knowledge between the Baltic socialist republics and other European states. It was necessary to find roundabout ways of introducing the innovative-minded global spirit, combined with the local architectural traditions and the actual possibilities established already in the 1920s and the 1930s.

The aim of the article is to recognize the cultural and historic significance of buildings of performing arts, i.e. concert halls, cinemas and theatres, and determine their role in the history of Latvian architecture. In order to achieve this, it is necessary to evaluate architectural qualities of performing arts buildings both in the context of stylistic trends of the epoch and in the broader geographical context. Uncertain understanding of the place of the Latvian cultural heritage on a European level prompted an in-depth analysis of buildings of performing arts in Latvia's Modern Movement.

Keywords: cultural heritage, history, Latvia's architecture, performing arts, Soviet period.

\section{Introduction}

After WWII, the Soviet Iron Curtain impeded sharing of knowledge between the Baltic socialist republics and other European states. It was necessary to find roundabout ways of introducing the innovative-minded global spirit, combined with the local architectural traditions and the actual possibilities established already in the 1920s and 1930s.

During World War II, several cities like Jelgava and Gulbene were almost leveled to the ground; the new principles of land management policy changed the traditional rural landscape. In the post-war period though, a number of significant public buildings, new housing estates, grand civil engineering structures and other buildings were constructed in Latvia. Today the Soviet relics have become part of Latvia's scenery and their preservation and development should be a responsibility of new generations of architects and historians and the general public as well.

It is quite important to perform the inventory of buildings of cultural establishments ascertaining their typology and stylistic features. It would allow defining more objectively the place of Latvian architecture in the European context, and determining further guidelines for development of cultural heritage.

The aim of the study is to make an inventory of buildings of performing arts and their stylistic and functional features, and analyzing an overall development process of various types of buildings in the second half of the $20^{\text {th }}$ century, to determine how the prevailing stylistic trends in the world, having blended with the local building traditions, had influenced and defined the place of Latvian architecture and cultural heritage in the European context.

\section{Methods}

Several research methods have been applied. The study is based on the analysis of the architecture of performing arts buildings. Basic information about the buildings has been collected, systematized and classified. A number of unpublished sources and archival materials have been discovered and a method of monographic and historical approach has been used. The buildings have been identified, surveyed and photographed, and a comparative visual analysis has been performed.

\section{Results}

In the late $1950 \mathrm{~s}$, when construction of large-scale residential districts began in the cities of Latvia using prefabricated building constructions (Krastinšs et al. 1998), the same degree of industrialisation was also applied to the architecture of public buildings. Designing institutes developed several standard designs for movie theaters, rural clubs, community centers and other establishments. Designing of the most significant public buildings received 
wide coverage. Numerous sketch design competitions were held, which fostered development of a talented generation of Latvian architects. Buildings of performing arts were constructed according to individual designs. Until the early 1990s, architects' contribution to Modern Movement was considerable, and its influence is still present today both in the capital city and in towns.

The structural principle of the analytical part is typological. Buildings of performing arts are divided in three typological groups - open air stages, which include summer concert halls, movie theatres and theatre buildings.

Some prominent personalities like architects Modris Ģelzis and Marta Staña played a significant role in introduction of modernist traditions. One of the most wellknown public buildings outside Riga is the summer concert hall in Jūrmala (architects M. Ģelzis and Alberts Vecsīlis, 1959-1960). The architects took into consideration the picturesque environment creating an open inner space in the wonderful landscape of seaside dunes. The successful setting in the environment allowed avoiding external walls that are usually necessary for acoustic needs. The surrounding dunes are used for relaxation and walks during intermissions. Also today this place has still retained the sense of spatial continuity.

In the early 1960s, light music had taken centre stage encompassing also art and cinema. In 1965, the popular and beloved composer Raimonds Pauls became manager of Riga Light Music Orchestra. In 1967, the joint concert of light music bands in Liepāja on the stage "Pūt vējinin" ("Blow, wind, blow") was given the name "Amber of Liepāja". It was attended by about 30,000 spectators (Kreituse 2010). The stage "Pūt vējiņi" in Liepāja was designed in 1961. Today, however, it is in a very poor condition and requires extensive modification for its further development. Several proposals for transformation were submitted at the open sketch design competition which ended in 2011. All architects mostly used a considerate approach offering to retain the existing stage structure, preserving spatial qualities and a relation with the coastal scenery, creating a new roof construction (Fig. 1 and Fig. 2).

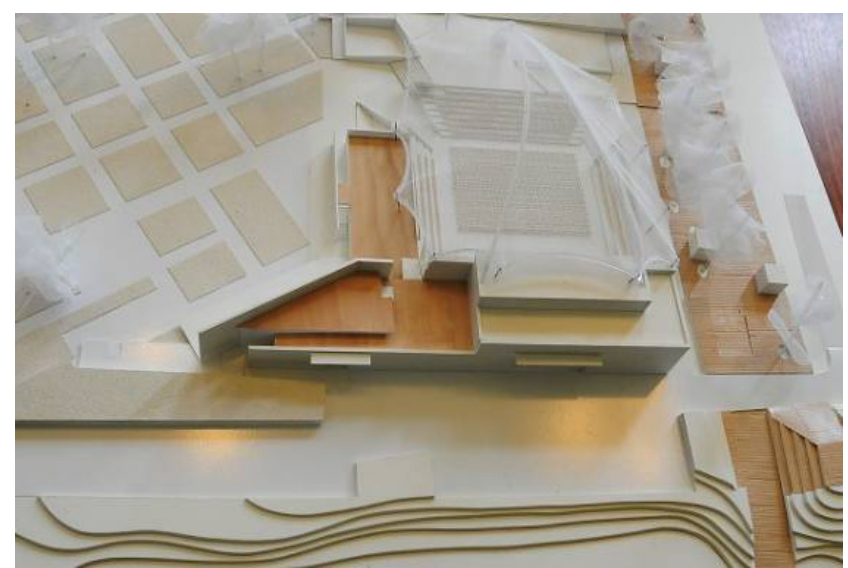

Fig. 1. A remodelling proposal for the concert garden "Pūt vējini in Liepāja. "Kokin Idea” LTD, 2011 (Reconstruction ..., 2011)

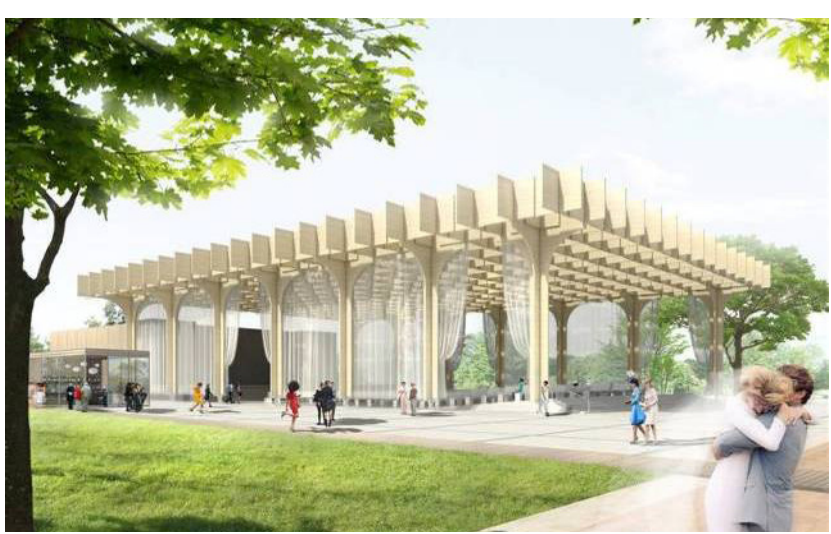

Fig. 2. A remodelling proposal for the concert garden "Pūt vèjiņi" in Liepāja. "Mark arhitekti" LTD, 2010 ("Mark arhitekti" LTD, 2010)

The architecture of open-air stages of Jūrmala and Liepāja tended to retain the relation with the surrounding scenic environment. The main concept was based on transparency of massing and organic continuation of the scenery in the interior. Their concepts seem to be inspired by the Finnish architect Alvar Aalto and his humane treatment of landscape transformation.

Already in the pre-war period, the relationship between the traditions of local building craft and European architecture was quite close in Latvia. In order to expand their knowledge, architects travelled around northern Europe and visited also largest Italian and German cities (Kampe 1929). The Iron Curtain put paid to those trips, however, there were a number of magazines available in Russian, which analyzed the works of Alvar Aalto, Le Corbusier, Niemeyer and other world-renowned architects (Современная архитектура 1964-1974, Савицкий 1972). Assimilation of the traditions of local schools of architecture and the latest trends in Modern Movement in the world most boldly manifested in several competition entries.

The competition entry developed by architect Marta Staña in 1968 for an open-air stage in Jelgava ("Mark arhitekti" LTD, 2009) illustrates the blending of deep-rooted folk traditions and aesthetic principles of Modern Movement into a single architectural image (Fig. 3 and Fig. 4).

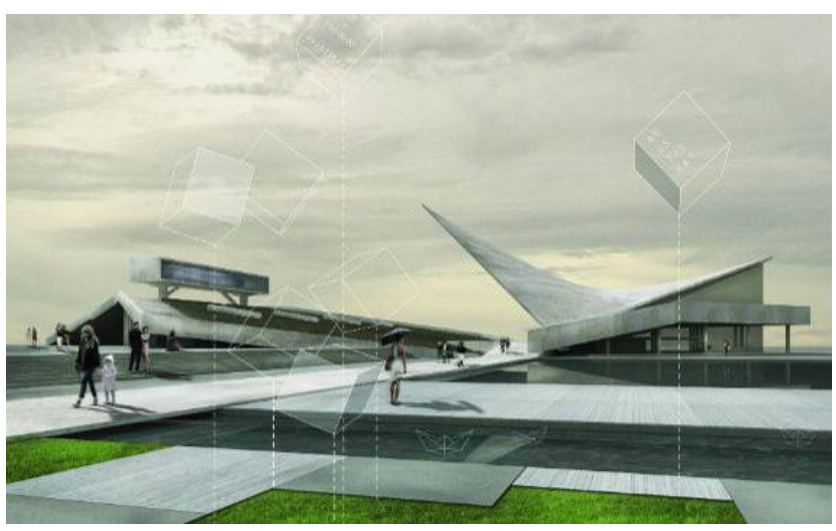

Fig. 3. A competition entry for an open-air stage in Jelgava, 1968. Architect Marta Staña. Authors of visualisation "Mark arhitekti" LTD, 2009 ("Mark arhitekti” LTD, 2009) 


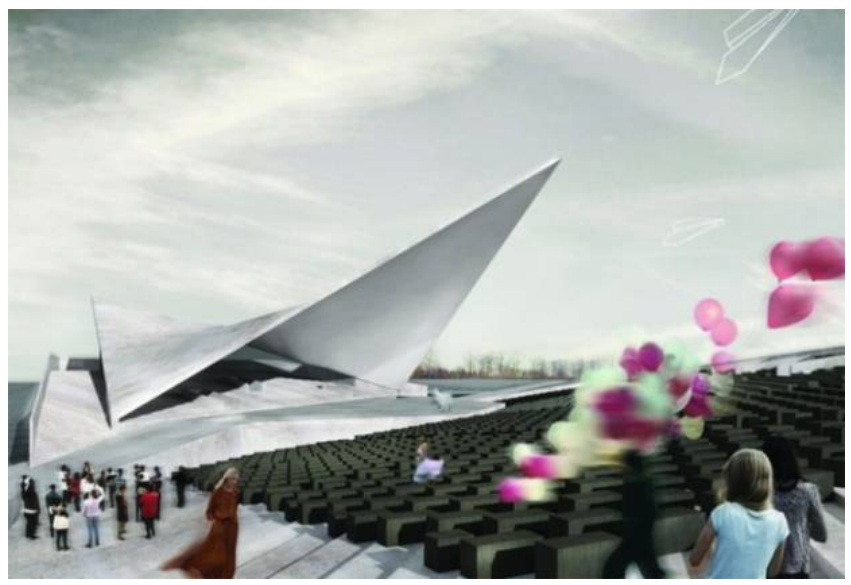

Fig. 4. A competition entry for an open-air stage in Jelgava, 1968. Architect Marta Stana. Authors of visualisation "Mark arhitekti" LTD, 2009 ("Mark arhitekti" LTD, 2009)

Aesthetic qualities of the exposed reinforced concrete structures of the open-air stage and juxtaposition of curves and straight lines bespeak the plastic forms used by $L e$ Corbusier and Niemeyer. The architect had avoided any decorations, using instead a technologically sophisticated structure within a proportionate and well-balanced composition. Exposition of structures was a trendy feature. However, such bold ideas could not be implemented in the Soviet Union because of bureaucratic hurdles, and very often, like in this case, the ideas did not materialize.

The design for one of the most well-known buildings in the Soviet Union, which was designed by Latvian architects, was also selected as a result of a competition. In 1956, the State Committee for Cinematography organized a competition for an architectural solution of the Panorama movie theater in Riga. First prize was not awarded, but second prize was given to the design elaborated by architects Oḷgerts Krauklis and Daina Dannenberga. The design was not implemented in Latvia. However, after its exhibition in Moscow, the movie theater was built in Celinograd (now Astana in Kazakhstan). In 1962, Krauklis and Dannenberga worked on location in Celinograd. According to the architect, it was a real "school of life" (Dannenberga 2011) and its outcome was the movie theater with 2500 tiered seats. The building can be used not only for exhibition of films but also as a venue for congresses, conferences and concerts. The acoustic solution was developed by Latvian architect Alberts Vecsīlis. Perhaps the high quality of acoustics is the reason allowing using the movie theatre to the present day. The architecture of the building displays features of Modern Movement. Huge expanses of glass alternate with sections of rendered walls. The building has a harmonious image and a clear center of the spatial composition.

The ideas of open plan and Modern Movement rapidly spread in the mid-1960s. Movies were acknowledged to be folk art, and movie theatres were built extensively. Open design principles have been applied in construction of several movie theatres in the historic centre of Riga, e.g. the movie theatre "Palladium" and the movie theatre "Pionieris".

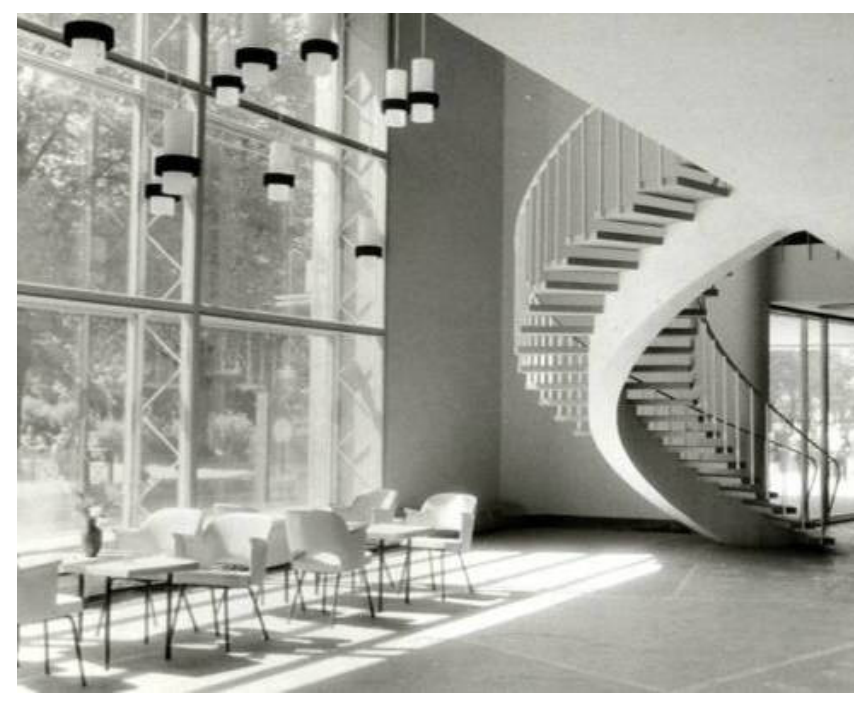

Fig. 5. The foyer of the movie theatre "Pionieris", architect Juris Pétersons, 1962 (Foyer..., 2012)

The construction of the movie theatre "Palladium" was begun already in 1913. The round shaped auditorium was built in the courtyard of the "Perpendicular" Art Nouveau apartment house (architects Edgar Friesendorff and Otto Lantzky, 1910). The existing structures at the back of the plot were remodelled in 1925 in remarkable style of Art Deco (architect Pavils Drejmanis). The movie theatre was renovated twice after the fires in 1957 (architects Modris Ģelzis and Artūrs Reinfelds) and in 1965 (architect Ojārs Dombrovskis), each time in up-to-date formal and spatial expression. "Palladium" opened its doors again in 2011. It was renovated by an architect office "Arhitekti Argali" LTD. The auditorium's powerful and elegantly balanced architecture is retained. Nowadays it could seat more than 2000 visitors.

In the architecture of the movie theatre "Pionieris" (architect Juris Pētersons, 1962) an attempt has been made to create relative boundaries that would spatially organize the visitors but would not separate the interior spaces from the architectural saturation of the adjacent historic buildings and the greenery of Esplanade - one of the central parks of Riga - on the opposite side of the street (Fig. 5).

Discussions about the implementation of modernist ideas in the relatively dense urban environment have been initiated in Latvia several times. A glass parallelepiped of the new building of the movie theatre "Spartaks" (architect Marta Stana, 1967) creates a transparent curtain which covers from view the lavishly decorated portal of another movie theatre "Splendid Palace" (architect Fridrihs Skujiņš, 1923). Perhaps the squalid surroundings, controversial conversion and inappropriate function (the building currently houses a casino) are the reasons preventing local inhabitants from enjoying the architectural qualities of the building. The architecture of the movie theatre seems to be inspired by the works of Mies van der Rohe who liked multiplication of one structural element. The result is a pure, geometric shape which emphasizes and highlights the basic values of Modern Movement - asceticism and simplicity (Fig. 6). 


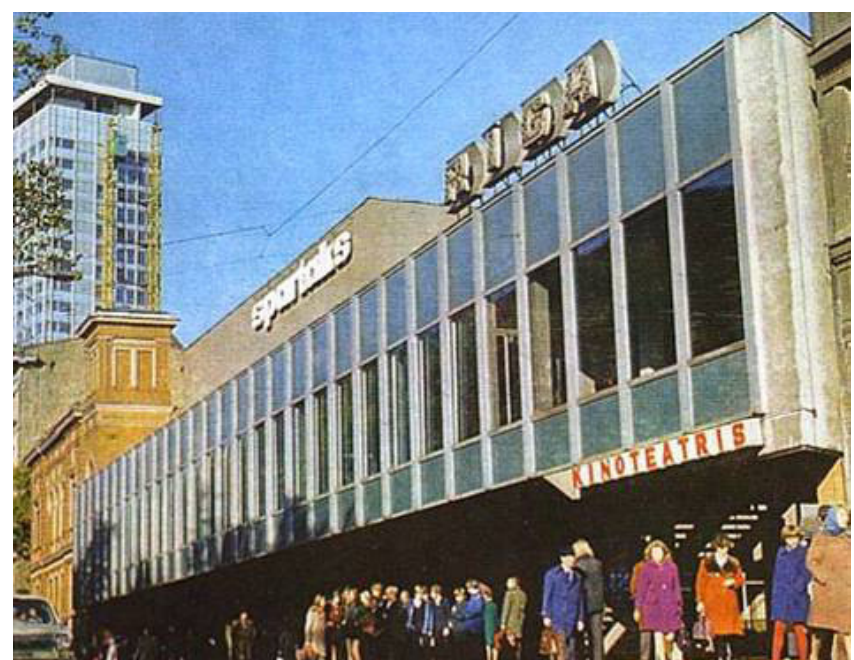

Fig. 6. The movie theatre "Spartaks", architect Marta Stana, 1967. Photography of 1970-ties (Movie..., 2012)

In ten years Modern Movement spread to the other cities of Latvia as well. The building of the movie theater in Daugavpils (architects Oḷgerts Krauklis and Maija Skalberga, 1981) displays the principles of Modern Movement and the use of local building materials and building traditions established during the pre-war period (Fig. 7 and Fig. 10). Having resemblance to the House of Culture in Helsinki, built in 1959 to the design by Alvar Aalto, the streamlined external contour of the building and a monumental brick wall highlight the expressiveness of the Daugavpils movie theater (Fig. 9).

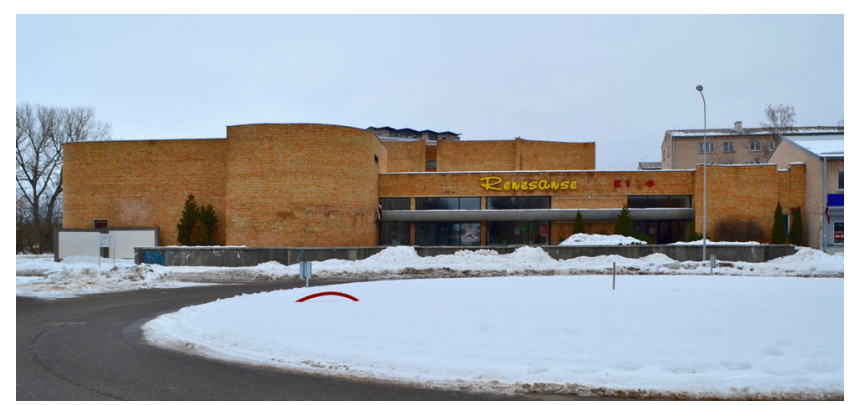

Fig. 7. The movie theatre in Daugavpils, architects Olgerts Krauklis, M. Skalberga, 1981

Along with the development of cinema, Latvian theatre had great success in the Soviet Union. The performances of the Daile Theatre on tour received much acclaim in Moscow.

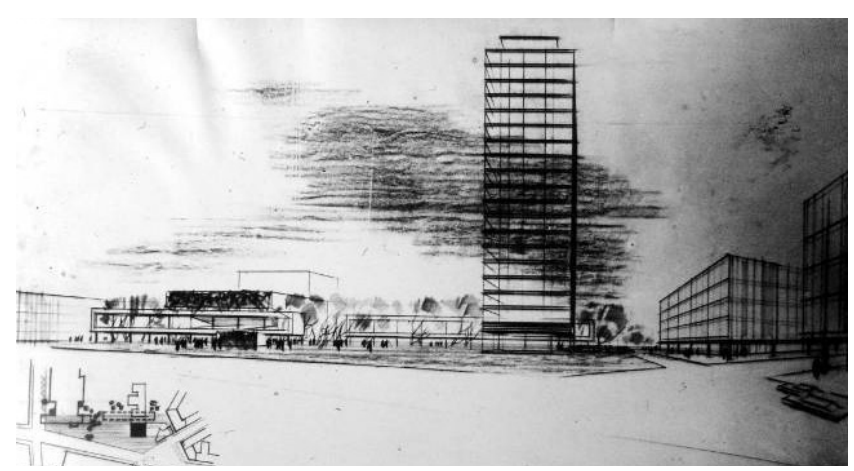

Fig. 8. A sketch of the Daile Theatre in Riga including a prospective vision of a high-rise, architect Marta Stana, 1960-ies

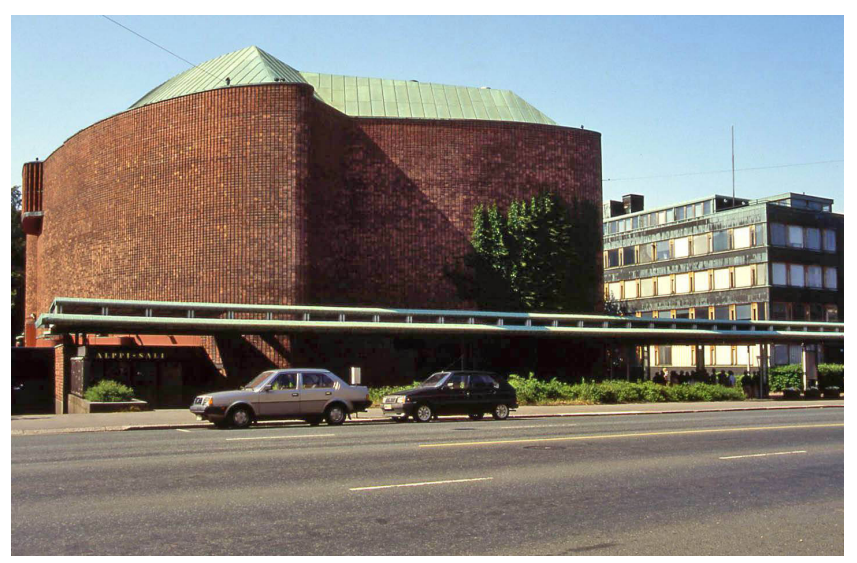

Fig. 9. House of Culture in Helsinki, architect Alvar Aalto, 1958 (Krastinšs, 1992a)

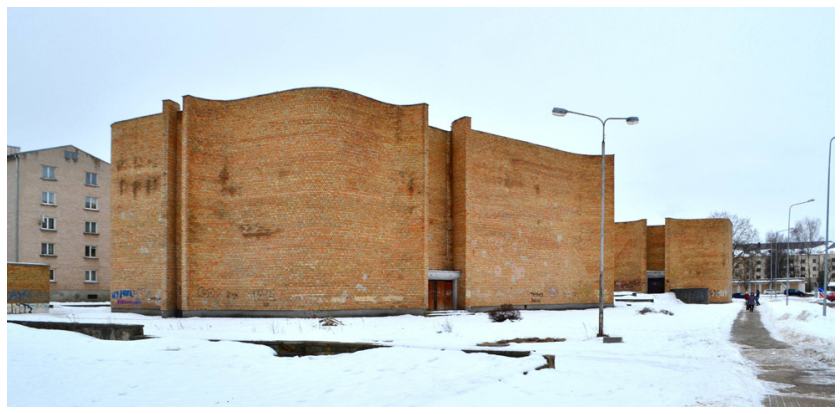

Fig. 10. The movie theatre in Daugavpils, architects Olgerts Krauklis, M. Skalberga, 1981

In 1959, the competition was held, where the design with the motto " 1111 " by Marta Stana and Tekla Ievina won first prize being the best among 26 entries (Banga 2012). The complicated designing and construction process lasted 17 years, and architects Imants Jākobsons and Haralds Kanders completed the project already after Marta Stana's death. The building of the Daile Theatre was part of the main urban planning axis of Riga or development concept for Brīvības iela, with its basic element being "a two-storey paviliontype building raised on pillars at a ground-floor height" (Krastinšs 2010). To make the two-storey glass structure appear more effective it was intended to accentuate it with the towers. In the sketch drawn by Marta Stana in the 1960s, next to the theatre building there is a high-rise, which was never built (Fig. 8).

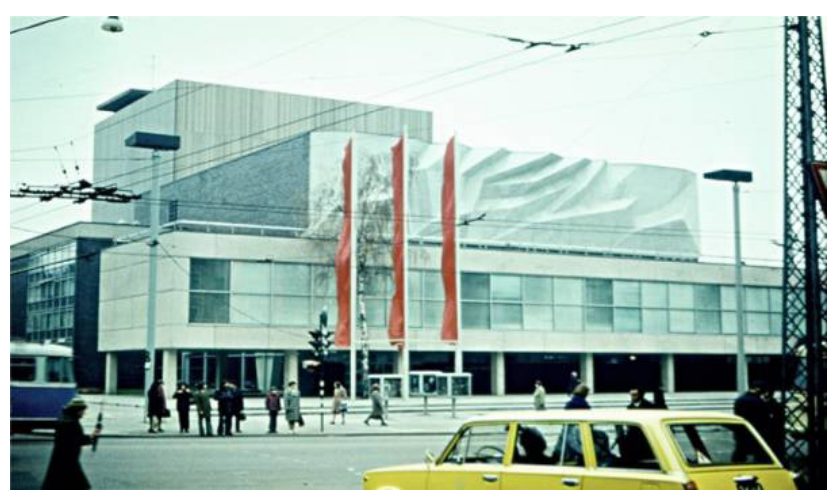

Fig. 11. The Daile Theatre in Riga, architects Marta Stana, Imants Jākobsons, Haralds Kanders, 1959-1976. Photography of 1970-ties (Daile..., 2012) 


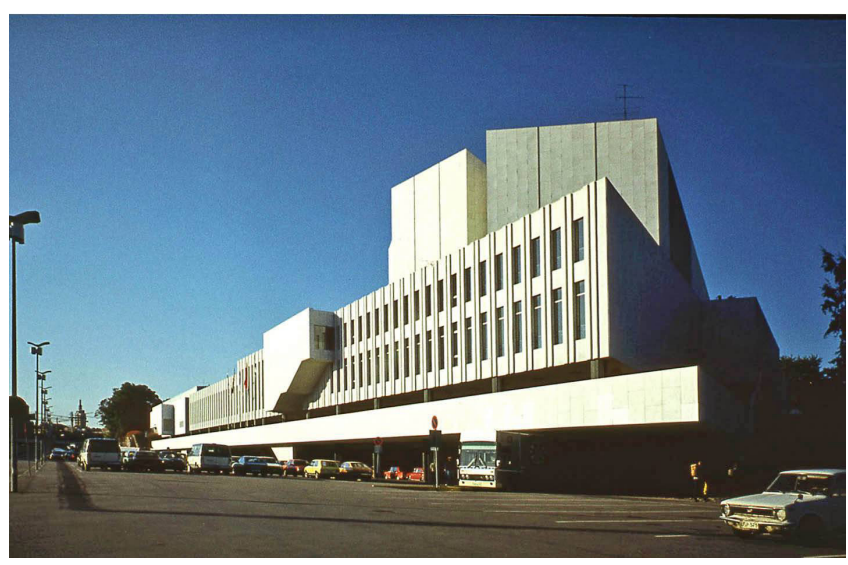

Fig. 12. Finlandia Concert Hall in Helsinki, architect Alvar Aalto, 1962-1975 (Krastinnš, 1992b)

Although in the course of designing the massing of the Daile Theatre was altered several times, the completed building generally reflects the concept of the original competition entry. A two-storey glass foyer with an integrated auditorium and stage is complemented with a strong dynamic accent. It is enlivened by a relief boasting a dramatic motif of flames by sculptor Ojārs Feldbergs. The flame motif, the widely used logotype of the theatre, was successfully interpreted by the sculptor, becoming the impressive part of the architectural composition. The theatre building is well perceived from several adjacent streets. Its peculiar massing provides interesting views from all sides the main entrance, the actors' entrance and the nearby public garden what is very important for such significant public objects.

The architecture of the Daile Theatre relies heavily on reinforced concrete structures and finish materials. Concrete columns stand exposed in the interior creating a contrast with the large expanses of glass. The finish of exterior spaces creates a harmonious overall image through the application of reinforced concrete, brown textured bricks, dark anodized aluminium and granite.

The architecture of the Daile Theatre bespeaks national self-confidence through excellence in performing arts and Modern Movement, which Marta Staña explored studying at the Faculty of Architecture of Latvian University under the guidance of Ernests Štâlbergs. She was the first woman who graduated the faculty after the war in 1945. Like many other talented architects, in 1951 lecturer Marta Stana had to leave the university as "an unwanted follower of rational architecture" (Banga 2012). However, difficulties only strengthened architect's character and today her works can be compared to Alvar Aalto's great masterpieces. Like Finlandia Concert Hall and Convention Center in Helsinki (Weston, 1995) built between 1962 and 1975, the Daile Theatre is the landmark of the capital city and a unique example of Modern Movement (Fig. 11 and Fig. 12).

After World War II, a strong school of architecture with distinctive national features and accents had formed in Latvia. The singularity revealed itself directly only occasionally, most often it was indirect and defined by the nature of the materials and structures used, the relation to cultural traditions and folk art, the surrounding environment etc. At the same time architecture became international and it was determined by several factors, namely, the synthesis of values and mass production requirements, standardization of designs and emphasis on functionality at the expense of aesthetic qualities. Therefore, the architecture of Soviet Latvia can be compared to the works of those European architects which reflected a similar understanding of values.

Quite often the neglected area around the buildings of performing arts hinders perception and understanding of modernist architecture. A larger attention should be paid to the lack of quality of the exterior spaces surrounding the buildings. It is also necessary to explain the ideological role of monumental and decorative arts, the importance of decorative sculpture in organization of interior and exterior spaces and the need of street furniture in the public open space. Sometimes as a result of present-day conversions the works of fine arts are lost. A particular attention should be paid to the problems of regeneration of the architecture of the performing arts buildings of the Soviet period.

\section{Discussion}

Several issues arise in the context of preservation and development of the Soviet heritage:

- The prevailing psychological and political prejudices hinder an objective assessment of the buildings constructed during the respective period. For quite a long time, the architecture of the respective period was associated with the worst manifestations of the regime; therefore the public was not prepared to accept the architecture of these buildings as part of unique cultural heritage.

- The role of performing arts buildings constructed during the Soviet period in the world cultural heritage of the respective period has not been defined.

- Today the evaluation of the legacy of the Soviet period changes and the attention is paid to individual architects and their creative achievements.

- The quality of construction is not always satisfactory and structures are not always durable.

- No attention was paid to accessibility of buildings because the Soviet statement was "there are no disabled people at all". It is our task today to find a solution to this problem. In Riga, these problems concern several conceptually open design examples, e.g. the State Philharmonic (reconstructed after the fire in 1963 by architects Modris Gelzis, Vera Savisko) and the Daile Theatre.

- Considering the fact that the buildings are relatively new (not older than 50 years), they are not regarded as a cultural heritage value. Nowadays exceptions exist. In 1998 the Daile Theatre was included into the list of the protected monuments.

\section{Conclusions}

There is still an issue of the role of architecture of cultural and entertainment buildings in the context of the world cultural heritage of the respective period. Significant buildings of performing arts were built in Latvia at the same 
time when similar buildings appeared in the other European countries. Their architectural quality and aesthetic richness is equivalent. This allows treating them as excellent examples of Modern Movement which need to be preserved and promoted at the European level.

Focusing on certain architects and their works would be one of the possible ways how to preserve and develop properly architectural heritage of the Soviet period and raise awareness of its significance, thus also treating architecture as art. There already have been several retrospective exhibitions which focused on architects Modris Ģelzis and Marta Stana and explored possibilities for conversion of several buildings of the Soviet period.

The values of Modern Movement are recognized at a very slow pace in Latvia. In future the architecture of Modern Movement should be divided into several stylistic groups. Even though some attempts of stylistic classification of Modern Movement in Latvia already exist, those were felt into neglect. Nowadays stylistic varieties can be distinguished taking into account the general evolution of the style blending with local traditions, e.g. regional cubism and minimalism, which would include aesthetics of "boxes", and plastic humanism, which would refer to modernist attempts to blend with the surrounding environment. Similarly, characteristic approaches of certain architects can be distinguished, e.g. avant-garde of Marta Stan,a, regionalism of Modris Ģelzis or functionalism of Olgerts Krauklis etc. Thus, it would be easier for the local community to identify them as part of their national architectural and cultural heritage.

\section{Acknowledgment}

This work has been supported by the European Social Fund within the project «Support for the Implementation of Doctoral Studies at Riga Technical University».

\section{References}

Banga V. 2012. Marta Staṇa un Dailes teātra kolīzijas. In: Ābele, K., Personība mākslas procesos, Neputns, Rīga, 2012, 198-212. [Banga, V. 2012. Marta Stanna. The Daile Theatre Disputes. In: Ābele, K., Personality in the Processes of Art, Neputns, Riga, 2012, 198-212.]

Daile Theatre in Riga. Available at: http://www.a4d.lv/lv/ notikumi/izstades-dailes-teatra-90-gadu-jubileja/ (accessed 20 April 2011).

Dannenberga D. 2011. Materials from the archives of architect Daina Dannenberga.
Foyer of the movie theatre "Pionieris". Available at: http://www. dizainastudija.eu/index.php/lv/1/112/785/788/index.html (accessed 20 April 2011).

Krastinš̌, J. 1992a. House of Culture in Helsinki, picture. Material from the archives of architect Jānis Krastinšs.

Krastiņš, J. 1992b. Finlandia Concert Hall in Helsinki, architect Alvar Aalto, 1962-1975, picture. Material from the archives of architect Jānis Krastiņš.

Krastinš̌, J. 2010. Changing Ideals of Modernity: Brīvības iela in Riga. In: Scientific Journal of Riga Technical University Architecture and Urban Planning, Series 10, RTU, Riga, 2010. Vol. 4, 30-36.

Krastinš̌ J., Strautmanis I., Dripe J., 1998. Latvijas arhitektūra no senatnes līdz mūsdienām. Baltika, Rīga, 1998, 312 lpp. [Krastinšs, J., Strautmanis, I., Dripe, J. Architecture of Latvia from Ancient Times till Nowadays. Baltika, Riga, 1998, 312 p.]

Kreituse I. 2010. Pagājušo gadu Latvija 1945-1990. Zvaigzne ABS, Rīga, 2010, 134-153. [Kreituse, I. 2010. Yesteryear Latvia 1945-1990. Zvaigzne ABS, Riga, 2009, 134-153.]

Kampe P. 1929. Aleksandrs Vanags 1873.-1919. kā cilvēks un kā celtnieks. J. Pētersons un biedri, Rīga, 1929, 20 lpp. [Kampe, P. 1929. Aleksandrs Vanags 1873.-1919. like a person and like a builder. J. Pētersons associate, Riga, 1929, 20 p.]

“Mark arhitekti" LTD, 2009. A competition entry for an open-air stage in Jelgava, 1968, picture. Material from the archives of,„Mark arhitekti” LTD.

"Mark arhitekti" LTD, 2010. A remodelling proposal for the concert garden "Pūt vējiņi”" in Liepāja, picture. Material from the archives of,,Mark arhitekti" LTD.

Movie theatre "Saprtaks". Available at: http://www.citariga.lv/ lat/rigas-apskates-vietas/pirmas-brivvalsts-laiks/kino-riga/ (accessed 20 April 2011).

Reconstruction proposal for the concert garden "Pūt vējiņi" in Liepāja. Available at: http://www.a4d.lv/lv/projekti/putvejini-konkursa-uzvaretaju-projekts/ (accessed 20 April 2011).

Sketch by architect M. Staña of 1960-ies of the Daile Theatre in Riga including a prospective vision of a high-rise, picture. Material from the archives of architect Daina Dannenberga.

Weston, R., 1995, Alvar Aalto. Phaidon Press Limited, London, 1995, $240 \mathrm{p}$.

Савицкий Ю. Ю, 1972. Архитектура капиталических стран. Стройиздат, Москва, 134 C. [Savickij, Y.Y, The Architecture of The Capitalistic Countries. 1972. Stroyizdat, Moscow, 134 p.]

Современная архитектура, 1964-1974. Издателъство литературы по строительству, Москва, 1964-1974. [Contemporary Architecture, 1964-1974. Publishing House of Construction, Moscow, 1964-1974.]

Agate ENIN,A - PhD student at Riga Technical University, Faculty of Architecture and Urban Planning.

Main research areas: the architecture of cultural and educational establishments in Latvia.

Address: Āzenes Street 16/20-420, LV-1048, Riga, Latvia.

Tel.: $\quad+37128380477$

E-mail: agate.enina@inbox.lv 